International Journal of Housing Markets and Analysis, 2012

Vol. 5 Issue: 2, pp.196 - 210

This article is (C) Emerald Group Publishing and permission has been granted for this version to appear here (http://dspace.mah.se/).

Emerald does not grant permission for this article to be further copied/distributed or hosted elsewhere without the express permission from

Emerald Group Publishing Limited.

www.emeraldinsight.com

\title{
Slumlords in the Swedish welfare state:How is it possible?
}

\begin{abstract}
Purpose: The artide tries to explain how long-term mismanagement of a honsing estate could arise in a country with a strong legal framework airned at preventing such situations.

Approach: Assuming that both tenants and landlord are rational, the artide presents a set of hypotheses that is consistent with the information available.

Findings: It is argued that the tenants stayed even though the rent was higher and the quality was lower than in neighboring areas because of a combination of three factors: Rents was paid by different forms of welfare payments, lack of alternatives because of queues to other areas and because some tenants saw an advantage in the "no-question" asked policy that the slumlord followed. It is forther argued that the property owner found this slum-strategy profitable either because they hoped to find a "bigger fool" to sell to andfor because the decision makers in the company bad not invested their own money. Both tenants and investors were in the end losers, but not the company managers.

Practical and social implications: The Swedish legal framework is to a large extent based on the idea that tenants should take action when there are problems. For several reasons the tenants in the area did not do that and it indicates that a more active role for the local authorities is necessary.
\end{abstract}

Originality: The artide focus on an interesting case that most people thought could not occur and tries to explain this within a framework of rational actors.

Keywords: slumlord, rental housing, neglected maintenance, speculative investors 


\section{Introduction}

\subsection{Background}

Housing quality in Sweden is very high by international standards. Municipal housing companies with a broad tenant base are the dominating landlord in the rental housing stock. In order to buy a property with rental apartments you have needed a permit from the municipality. There are laws saying that buildings must be maintained and a law about "receivership" which means that the tenants can deposit their rent at a public authority and go to court if the owner mismanages the property. ${ }^{1}$ The court can then appoint a management company that takes care of the property for a specific time, and the management company is paid from the deposited rents. Typically this has happened for small properties owned by single persons or small companies, and there have only been a few cases per year in the whole country. Sweden also has a strong tenant's union that together with the strong legislative framework should guarantee that everyone lives in an apartment with good quality and that the property is taken care of in a professional way.

It therefore came as a surprise to most people in 2008 when a TV-program known for unraveling scandals described the condition in a large housing estate in Malmö (part of an area called Herrgården). ${ }^{2}$ The program showed an estate with bathrooms full of mold, and with cockroaches and lice in overcrowded apartments. The hallways were full of graffiti and had many broken windows. Outside there was a lot of litter and garbage. The owner had obviously reduced maintenance expenditure to almost zero in order to maximize the net operating income. In the Swedish context this is called a slum area.

\subsection{Purpose and method}

The basic purpose of this article is to discuss how this could happen. What mechanism can have led to this condition that the general public, authorities and politicians thought could not arise in Sweden? From the beginning we want to underline that this is a speculative article. For reasons that will be clear later it is almost impossible to collect evidence that could substantiate some of the hypotheses more definitely.

The method used can be seen as type of hypothetical-deductive method in the spirit of Karl Popper (see e.g. Popper 1963). The analysis starts with the surprising observation of large scale slum in modern areas in Sweden. With a theoretical background in economics a number of possible explanations - conjectures - were formulated within the framework of utility maximizing individuals and pareto-optimality. These theories were then confronted with all the empirical evidence we could get hold on with a reasonable amount of resources to see if there were any information that could refute these conjectures.

\footnotetext{
${ }^{1}$ The law was recently changed but that was after the events analyzed in this article.

${ }^{2}$ That there were problems in the areas was however described in several studies already during the 1990s, see e.g. Ristalammi (1994), Popoola (1998,1999). This information did not however lead to any strong reactions and
} 
broader debates on housing policy, probably because the scale of the problems was smaller then compared to 2008.

One of us has been studying a similar nearby area that the municipal housing company MKB bought in 2006 and has also worked in the field in that area. This experience and contacts built up during that work has also been used to collect further information (see Blomé 2011).

The article could also be described as an attempt to put together a puzzle with a rather small number of pieces available. It is therefore more of a starting point for further work than something dose to the final explanation of how large slums could arise in Sweden.

The article is written within a rationalist economic framework, simply because we are economists. From a methodological perspective, the purpose was to see if it was possible to explain the development from an assumption that both tenants and property managers were rational. It is, however, important to underline that a study from a more phenomenological or anthropological framework would be very interesting. Such a study would give a deeper understanding of how people living in the slum-area see their options, and why they choose a certain alternative. Such information is necessary in order to more systematically test some of the hypotheses put forward in this article, but also in order to design policies that would work in practice.

\subsection{Structure of the article}

The structure of the article is as follows. In section 2 the area and its history is described and it is seen that the area has a long history of mis-management. Section 3 presents some general theories of slums that we will argue are not so relevant in the case under study. In section 4 our hypotheses concerning the behavior of tenants and landlord are presented together with the relevant evidence. In the concluding section the different parts of the explanation is put together within our rationalist framework. In the concluding section policy implications and ideas about future theoretical and empirical research can also be found.

\section{Description of the area and its history}

\subsection{The housing district Rosengård}

Herrgården is a part of a district called Rosengård. Most areas in Rosengård were constructed during 1965 to 1971, a part of the so called Million Homes Program in Sweden. Even though it is located rather dose to the city center, it never became an attractive area. The district has a population of around 22000 and a large percentage of these are characterized as socioeconomic disadvantaged households. In the 1980s and the 1990s many ethnic Swedes moved out from Rosengård which instead became a home for many newly arrived refugees transforming the area's population from homogeneous to more heterogeneous (see Molina, 2001). Many residents live their life in unemployment, dependent on public welfare, feeling that they were not a part of the Swedish society. Since the 1980s, various governmentsubsidized projects were carried out to improve housing qualities with a special focus on the outdoor environment. In the 1990s, field-related projects instead focused more on social 
projects but still many problems remained (Bevelander et al., 2000, 2001). This is the general picture, but actually there are large differences within the district of Rosengård.

Rosengård includes seven neighbourhoods which differ in type of tenure and social composition (see map in Figure 1). Apelgården and Kryddgården in the north consist mostly of tenant-owned cooperative housing ("Bostadsrätt"), which is a form of condominiums. Västra Kattarp in the south only has owner-occupied single family houses. Persborg, Örtagård, Tömrosen and Herrgården only consist of rental properties and there is an invisible boundary between these and the other neighborhoods in terms of socio economic situation (see e.g. Hallin et al., 2010 for more information about the general situation). Particularly, Örtagård and Törnrosen are similar to Herrgården regarding geographic location, construction year, social situation, demography and household- and apartment size. These neighborhoods, managed by the municipal housing company $\mathrm{MKB}$, were previously more problematic but are today considered to be rather well functioning large housing estates, in contrast to the most problematic part Herrgården which is in focus in this article. ${ }^{3}$

\footnotetext{
${ }^{3}$ Malmö staristics (2009).
} 
Figure 1: Map of Rosengård, Rosengård, with Herrgården located in the east.

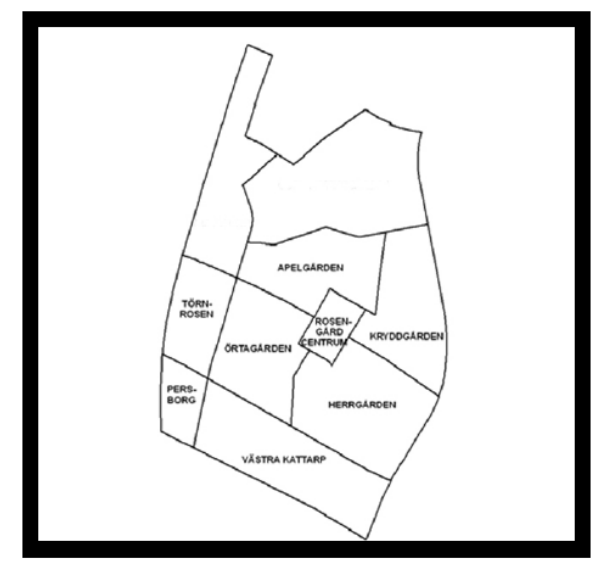

\subsection{The neighbourhood Herrgården}

Herrgården is located in the east of Rosengård, next to a small shopping center and surrounded by main roads in the north and east and the neighbourhood Västra Kattarp in the south. It was completed in the year 1967 and consists of 1360 apartments. It was then considered to be the best part of Rosengård. However, economic crisis in the beginning of the 1990s affected the neighbourhood in a negative way (Popoola, 1999) and a downward spiral started, probably because the area already then was managed less well than the areas owned by the municipal housing company MKB. Socially stronger households were moving out and refugees and unemployed households moved in and the area are today portrayed as Malmö's poorest overcrowded neighbourhood (Hallin, 2010). Herrgården is associated with segregation, poverty, social exclusion, poor mental health, vandalism, riots, fires, drugs and criminality and has become a prime example of a non-functioning neighbourhood. This is of course not the whole truth and some parts are functioning better than others. Herrgården has a significant concentration of people coming from other countries and 96 percent have other origin than Swedish, if both first and second generation is counted. In addition, the neighbourhood has 4878 documented residents and this is very high in relation to the number of apartments. According to police and social workers the true figure could be considerably higher due to illegal subletting and lodgers (Hallin et al., 2010). It should also be mentioned that up to 50 percent of the population are minors, and a large percentage of the adult population has never entered labor-market ${ }^{4}$

One important difference between Herrgården and other parts of Rosengård from an ownership perspective is that since 1997 the area has been divided between several private landlords. and has been characterized by many recurrent real estate transfers (Popoola, 1999, Hallin et al., 2010). In Table 1 below the transaction year and type of owner is described. Figure 2 shows a map of the area.

\footnotetext{
${ }^{4}$ Malmö staristics (2009).
} 
The owners are numbered within each category to make it possible to see how large share each owned. In other parts of Rosengård the rental properties has been owned by the same municipal housing company (MKB) since they were built. Malmö municipality was concerned with the situation in Herrgården and ordered the municipal housing company to acquire 294 apartments in r 2006 (22 percent of Herrgårdens housing stock). This is area (1) and (2) below and the "makeover" of these properties is analyzed in Blomé (2010). One important objective behind this purchase was to try to change the negative situation and create an example in order to motivate private landlords to renew their buildings, improve maintenance and their local housing administration. Areas (3) and (5)-(11) have been owned by the same foreign investment company since 2004 and it was in these areas that the slum described above developed.

Figure 2: Map of Herrgården.

Area $I$ and 2 are owned by the municipal housing company MKB.

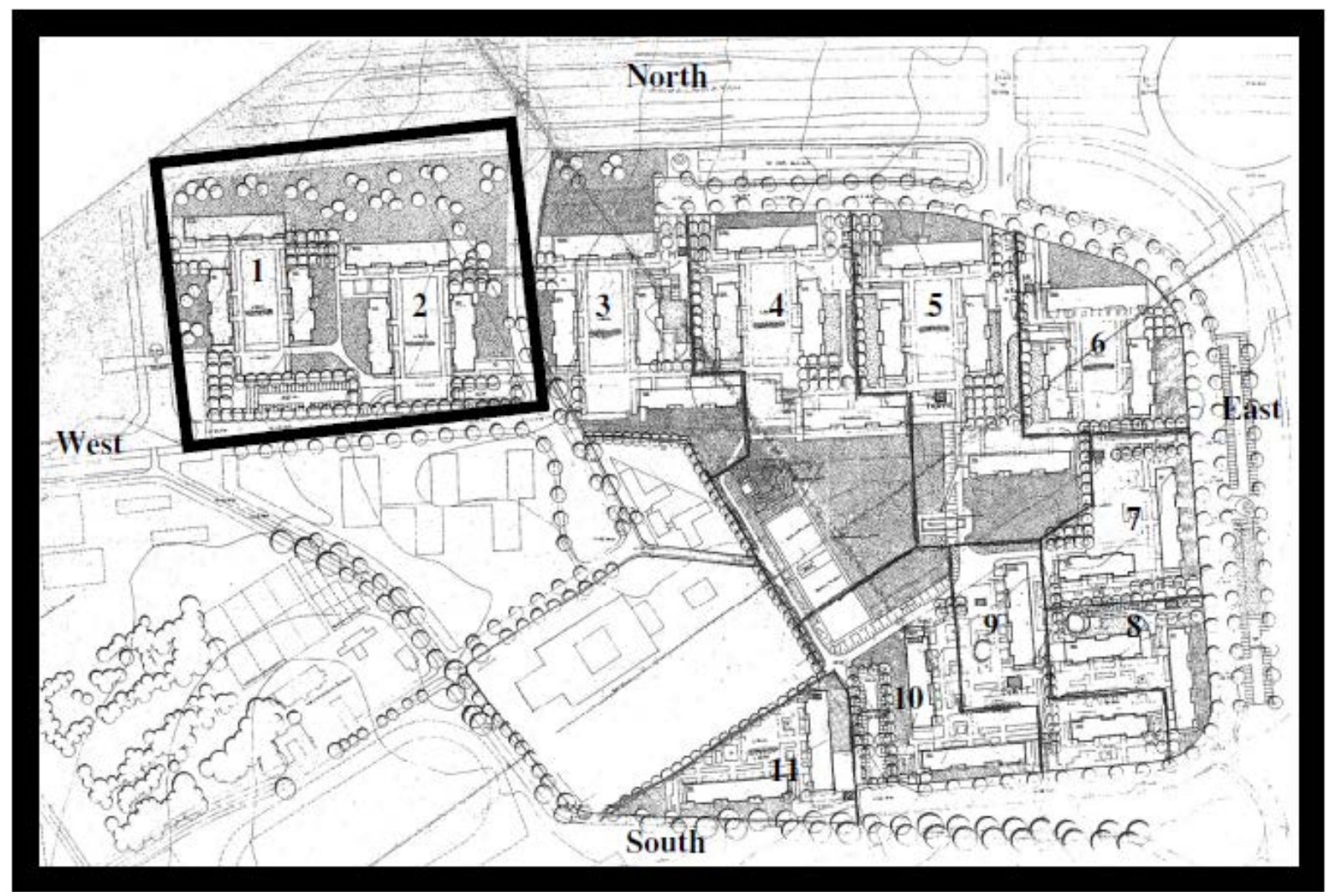


Table 1: land transfers between the years 1990-2010

Figures in parentheses refer to the areas in the map in Figure 2 below.

\begin{tabular}{|c|c|c|c|}
\hline The properties & Landlords & The properties & Landlords \\
\hline \multirow{3}{*}{$\begin{array}{l}\text { (1) Landsfiskalen } 1 \\
147 \text { apartments }\end{array}$} & \multirow{3}{*}{$\begin{array}{l}\text { 2006- Municipal Company (MKB) } \\
\text { 2003- Private Company } 6 \\
\text { 1996- Foreign Private Company } 2 \\
\text { 1994- Foreign Private Company } 1 \\
\text { Cooperatively Owned }\end{array}$} & (6) Krondirektören 5 & 2004- Foreign Private Company 3 \\
\hline & & 138 apartments & $\begin{array}{l}\text { 2003- Private Company } 7 \\
\text { 1997- Private Company } 4 \\
\text { Private Company } 2\end{array}$ \\
\hline & & (7) Krondirektören 6 & 2004- Foreign Private Company 3 \\
\hline \multirow{5}{*}{$\begin{array}{l}\text { (2) Landsfiskalen } 2 \\
147 \text { apartments }\end{array}$} & \multirow{5}{*}{$\begin{array}{l}\text { 2006- Municipal Company (MKB) } \\
\text { 2003- Private Company } 6 \\
\text { 1996- Foreign Private Company } 2 \\
\text { 1994- Foreign Private Company } 1 \\
\text { 1993- Cooperatively Owned } \\
\text { 1992- Private Company } 3 \\
\text { Private Company } 1\end{array}$} & 54 apartments & 2003- Private Company 7 \\
\hline & & & $\begin{array}{l}\text { 1997- Private Company } 4 \\
\text { Private Company } 2\end{array}$ \\
\hline & & (8) Krondirektören 7 & 2004- Foreign Private Company 3 \\
\hline & & 53 apartments & \\
\hline & & & 1997- Private Company 8 \\
\hline \multirow{2}{*}{$\begin{array}{l}\text { (3) Krondirektören } 2 \\
160 \text { apartments }\end{array}$} & \multirow{2}{*}{$\begin{array}{l}\text { 2004- Foreign Private Company } 3 \\
\text { 2003- Private Company } 7 \\
\text { 1997- Private Company } 4 \\
\text { Private Company } 2\end{array}$} & & Private Company 2 \\
\hline & & $\begin{array}{l}\text { (9) Krondirektören } 8 \\
113 \text { apartments }\end{array}$ & $\begin{array}{l}\text { 2004- Foreign Private Company } 3 \\
\text { 2003- Private Company } 7 \\
\text { 1997- Private Company } 4\end{array}$ \\
\hline \multirow{2}{*}{$\begin{array}{l}\text { (4) Kronodirektören } 3 \\
172 \text { apartments }\end{array}$} & \multirow{2}{*}{$\begin{array}{l}\text { 1996- Private Company } 3 \\
\text { 1994- Municipal Company (MKB) } \\
\text { Municipal Company } 2\end{array}$} & & Private Company 2 \\
\hline & & $\begin{array}{l}\text { (10) Krondirektören } 9 \\
92 \text { apartments }\end{array}$ & $\begin{array}{l}\text { 2004- Foreign Private Company } 3 \\
\text { 2003- Private Company } 7\end{array}$ \\
\hline \multirow[t]{2}{*}{$\begin{array}{l}\text { (5) Krondirektören } 4 \\
163 \text { apartments }\end{array}$} & \multirow{2}{*}{$\begin{array}{l}\text { 2004- Foreign Private Company } 3 \\
\text { 2003- Private Company } 7 \\
\text { 1997- Private Company } 4 \\
\text { Private Company } 2\end{array}$} & & $\begin{array}{l}\text { 1997- Private Company } 4 \\
\text { Private Company } 2\end{array}$ \\
\hline & & $\begin{array}{l}\text { (11) Krondirektören } 10 \\
94 \text { apartments }\end{array}$ & $\begin{array}{l}\text { 2004- Foreign Private Company } 3 \\
\text { 2003- Private Company } 7 \\
\text { 1997- Private Company } 4 \\
\text { Private Company } 2\end{array}$ \\
\hline
\end{tabular}

The foreign investment or asset management company that has owned most of the area since 2004 belongs to the Acta group who raised money from (mostly small) private investors and they invest in a large number of assets. Property management is outsourced to local companies. Jönsson (2005) describe the growth of this company, and a similar company called Cheops, into some of the largest owners of residential properties in Sweden and underlines a combination of very low equity and cheap finance that reduced the rate of returned demanded. The Swedish Financial Inspection (see www.finansinspektionen.se) has got a number of complaints about Acta and made special investigations of the company where one aspect is whether the company had given correct information about how risky the investments were. The development of Cheops (later bought by the now bankrupt Landic that was closely linked to one of the Icelandic banks) is described in Ahlgren \& Segerborg (2010).

Sweden had a very serious property and financial crises in the early 1990s. In the classification in Rinehart and Rogoff (2008) this crises belongs to the Big Five in the post-war period. Real estate prices were very low after the crisis and the price has risen dramatically during the whole period after 1995 (see Statistics Sweden 2010). Since 2003 the Swedish Property Index has presented a quality controlled price index and according to that index the average price for residential properties has increased with more than 50 percent between 2003 and 2007. Even if data on selling prices have not been available for the Herrgården transactions there are reasons to believe that all (equity) investors after 1995 has made considerable profits on their investment - at least up to 2009. 


\section{Theories of slum and their general relevance}

A slum, as defined by the United Nations agency UN-HABITAT, is a run-down area of a city characterized by substandard housing and squalor and lacking in tenure security. When the term is used in this article the focus is on the first part of this definition and the term substandard indicates that slum is a relative term, as what is seen as standard and substandard depends on the general income level in society. What is called slum in this article is not an area that is comparable to what is called slum in developing countries.

Most of the international literature on slums focuses on areas in poor countries, see e.g. Neuwirth (2006), but there is also a large American literature from the 50s and 60s about inner city slums in large American cities, see e.g. Stokes (1962) and Doran \& Landis (1980). An overview of the development can be found in Quigley (2000).

Central ideas in the literature on slums are the following:

- Slums as the reflections of low incomes. Migrants to large cities start in slum areas when their incomes are low and as incomes rises they might move to other areas. Low quality housing is then simply the consequence of the low income of the household.

- Slums as a reflection of a specific subculture. The American slums in the 60s and 70s was to a large extent dominated by Afro-americans and some areas developed into specific communities where households stayed even if their incomes increased, at least partly because of discrimination in other areas.

- Slums as the result of filtering and neighborhood tipping. Some of the American slums developed in areas that used to house higher income groups, but step by step households with higher incomes moved out and as the same time as housing quality deteriorated they were replaced with low income households and specific ethnic groups. Neighborhood tipping is for example analyzed in Feijten and van Ham (2009). In the Swedish debate it has also been underlined that this process also can be affected by stigmatization and that an area always is talked about as a "problem area" e.g. in the media (see e.g. Öresjö, 1996, Molina, 2001).

In the economic literature there is also a discussion of slum developing as a result of negative external effects and a Prisoner's dilemma situation. The idea is that it if the neighboring properties are run down it is not profitable to keep up the quality in a house, as it would still not be attractive when it is surrounded by low-quality housing. This can then contribute to a downward spiral that in the end also might lead to abandoned buildings (see O'Flaherty (1993) for a theoretical analysis).

The concept of slum has not been central in the Swedish debate on disadvantaged neighborhoods. The main focus has instead been on segregation (see e.g. Lilja \& Pemer 2010 for an overview) and the explanation for this is probably that even if segregation that at least partly is based on income leads to quality difference between areas, it does not have to lead to slums. It was believed/assumed that conditions even in the worst areas were so high that it would not be correct to call it a slum.

Looking at the Herrgården area from the perspective of the theories presented above there are some elements that obviously are relevant, especially the long-term downward spiral when the 
area step by step becomes more and more dominated by low income immigrant households with a weak relation to the Swedish labour market and the Swedish society in general.

However, most of the economic mechanisms do not seem to be relevant in our case. The households in Herrgården does not live there because they cannot afford other areas as the rent levels in Herrgården are at least as high as in "better" neighboring areas.

As the nearby neighborhood areas generally are of higher quality it cannot be argued that it is unprofitable to increase quality in the slum parts of Herrgården because of negative external effects from neighboring areas.

In the next sections some more specific hypotheses are presented and evaluated in relation to the information available.

\section{Hypotheses: Description, implications and evaluation}

\subsection{Introduction}

There are some initial observations/reflections that are important for understanding what can explain the development in Herrgården.

The first is, as mentioned above, that the rent level in Herrgården is not lower than in neighboring areas where the quality is higher. This means that the households living in these areas on average pay at least as much but get lower housing quality. In section 4.2 we therefore focus on the question:

- How can the company in Herrgården get tenants when the tenants seem to get low value for money compared to apartments in neighboring areas?

-From a company perspective this is the same as asking: How is it possible to combine high rents, low vacancies and low operating and maintenance costs - which of course generate a high net operating income)

The second observation is that the strategy followed by the company in Herrgården is not followed by other private owners in Malmö that also are assumed to be profit maximizing. The implication must then be that the strategy followed by the "slumlord" is not normally economically rational. The neglect of the properties should reduce the value of the property in such a way that even though the short run net operating income is increased by the "slum" strategy, the total profitability of this strategy is lower than following a more normal strategy with at least some maintenance of the property. In section 4.3 the profitability of the slum strategy is discussed in terms of an "exit strategy" - it is obvious that the slumlord strategy increases the short run net operating income, but why do the property company believe that this strategy is profitable in a longer perspective, taking changes in property values into account? This is discussed in section 4.3. 


\subsection{How can they get tenants?}

The possible explanations for why households live in an area that seems to give low valuefor-money are divided into three groups:

1. The households do not pay themselves, so the real value for money is higher than what it looks like.

2. The households get some other value, which also would imply that the real value for money is higher than what it looks.

3. The households have no real choice, so they have to accept an alternative that gives a low value for money.

\section{Households do not pay themselves?}

The rate of employment is low in the area and many households are living on different forms of payments from the public sector. Families with children can also get a housing allowance. We do not have any exact figures for specific apartment blocks, but there are reasons to believe that many of the household are not paying the rent with money from employment. As much as 83 percent (1128 households) has received public welfare suggesting that they get help with the rents ${ }^{5}$. From that perspective it could be argued that the households get a high "value for money" even if the housing quality is low.

The problem with this argument is, however, that if the households had been living in a neighboring area they would have the same type of public support, and then they would get higher housing quality, so there must be some other explanation for why they are staying in the area with the lowest quality?

\section{Households get some other value}

From a rationalist perspective, assuming some freedom of choice, the answer to why a household stays in an area with lower housing quality than other areas must be that there are some other advantages with living in this area. Some slum areas in developing countries is e.g. rather centrally located and might be chosen because they reduce cost for travelling to work. As we in this article compare with similar neighboring areas such external factors cannot be the explanation for choosing a low-quality area.

Another way to formulate this question is to ask what does the slum landlord "deliver" that is not delivered by other landlords? The only answer that we can come up with to this question isthat the slumlord delivers is a "No questions asked" policy.

For at least three groups of households this "no questions asked" policy has a value:

1. The first group uses the apartment for illegal activities (selling drugs, illegal gambling, prostitution) that a normal landlord would find out, but that the "slumlords" do not care about.

\footnotetext{
${ }^{5}$ Malmö statistics (2009).
} 
Reports in the media, information from police and managers of nearby areas indicated that this occurred to a larger degree than in other areas, but still it was only a small percentage of apartments used in this way.

2. The second group uses the apartment for illegal subletting, i.e. subletting that would not be approved by a normal landlord. The apartment may e.g. be sublet to person who illegally lives in the country or to other households that have few alternatives on the open market They could also sublet in a way that leads to overcrowding.

In the nearby block taken over by MKB in 2007, the first thing they did was to visit every apartment to find out who really lived there (see Blomé, 2010), Sometimes up to ten names was found on the door and it was clear that there was a lot of illegal subletting, even if no precise figure can be presented. It is very likely that it was the same in the blocks owned by the "slumlord".

3. The third group that can appreciate a no question asked policy is households of the following type. In recent years the number of refugees coming to Sweden from e.g. Iraq, Afghanistan and Somalia has been high. Initially these refugees tend to stay with friends and relatives and the consequence can be severe overcrowding in areas where there initially lived households from these countries. Such overcrowding is however not accepted by many landlords.

This overcrowding has been observed in a number of cases in Sweden in recent years, e.g. in Södertälje and Gothenburg. ${ }^{6}$ One way to identify overcrowding has been to monitor water consumption as there is a clear relation between water consumption and the number of persons in an apartment As ventilations in bathrooms are built given a certain expected usage, a number of problems, e.g. mold, occur rather quickly if an apartment is used by many more people than what it was built for. Some housing companies have introduced explicit limits on the number of persons living in an apartment. One advantage of living in a house owned by a "slumlord" is then that the landlord will not do anything to find out and take measures against overcrowding.

There are strong reasons to believe that overcrowding was severe in the rundown parts of Herrgården. Some of this overcrowding was legal in the sense that the persons had the right to live in the apartment and the exact share of the illegal subletting is impossible to know.

When the nearby blocks in Herrgården were upgraded, it was clear from interviews made by the company that the majority of the households had a very positive view of this upgrading. One of the authors - Gunnar Blomé - made some of these interviews. They appreciated more "law and order". Even if it seems clear that a considerable number of tenants appreciated the no questions asked policy, they were probably not the majority.

In response to comments that we have got during discussion about this paper it should be underlined that our point concerning criminal activities is only that criminal activity will tend to move to areas where the landlord is passive. Criminal activity can be found in all social groups and we are not suggesting that it is higher in e.g. certain ethnic or social groups.

\section{Households have no choice}

\footnotetext{
${ }^{6}$ The mayor of Södertälje - Anders Lago - were invited to the American Congress in 2009 to discuss refugee policies. More refugees from Irak was coming to Södertälje than to the whole of the USA.
} 
The third hypothesis is that the households living in the run down area have no choice. There are of course some elements of truth in this hypothesis too, even if there is a considerable turn-over in the areas, mostly between different blocks within the Rosengård area.

There is a housing shortage in Malmö and long queues to rental housing in other areas. Having lived in the Herrgården area and having a foreign background and no fixed employment can lead to households being rejected by other landlords.

One problematic feature of this hypothesis is however the following. Assume that the majority of the households have no alternatives and realize that they are stuck in the neglected area. They know that housing quality is higher in other areas of similar type, as they can compare with other parts of Rosengård. Why aren't they using the existing legal possibilities to improve their housing quality? Remember that this would not lead to higher rents. Why didn't the tenants long ago contact the Tenants Union that is strong in Sweden and get help to improve their situation? Why did the deterioration go so far without any action of this type from the tenants?

Even if many of the households in the area are rather new to Sweden, most of them can be expected to have friends and relatives that have been here longer and have more information about the legal possibilities. If households know that they are stuck in an area with lower housing quality than other areas they should have stronger incentives to try to improve the situation in the specific area: If the "exit" strategy is closed for many households then they should be expected to use the "voice" strategy instead.

One possible answer is that the households are "helpless victims", but that is not so convincing given that many of the households have been able to escape from their borne countries and come to Sweden. The competing hypothesis is then a combination of:

- That the household get advantages from the no-questions-asked policy of the landlord that compensates for the low housing quality.

- Fear: There might be threats from the first group of households. If you go to the Tenant's Union or the authorities and complain about the situation you might be punished by the first group of households. Instead of acting the household tries to move out of the area.

- Genuine lack of knowledge of the Swedish legal system both concerning what is seen as a reasonable housing quality and the legal possibilities that exist.

In the media it has been asked why the Tenant's Union did not act. The answer seems to be a combination of low membership rates (only 7 percent of all tenants 2008) and no initiatives taken by the households in the area ${ }^{7}$. As we will return to in the final section, it is the tenant's that is expected to complain if a landlord does not deliver a reasonable housing quality.

\subsection{How can it be profitable?}

Judging from strategies followed by the majority of the landlords, it is not a profitable strategy to neglect maintenance in the way that the company in the Herrgården area has done. The short run increase in net operating income is not enough to compensate for the fall in

\footnotetext{
${ }^{7}$ The membership number in the Tenant's Union have increased after 2008.
} 
value that the slum strategy leads to. A crucial question in then what kind of long-run plan the property owner in the area has.

There seems to be at least two possible strategies from the perspective of the decision makers in the company that owns the properties.

The first strategy can be described as a version of the "bigger fool theory" (see Lind, 2009). It might be possible to sell the properties at an irrationally high price, given the bad condition of the buildings. The sale to the municipality in 2006 occurred during a boom when the yield demanded by investors was low even for properties with low quality. Even if the municipality paid the market value, it could be argued that this market value was not really based on fundamentals. It is interesting to read in Ahlgren \& Segerborg(2010) about the Danish company Cheops, with at least some properties of the type in Herrgården was sold with an enormous profit to a real estate company controlled by Icelandic banks just before the banks crashed. Most of the company that bought the properties (Landic) later went bankrupt. These cases illustrates that it might be possible to get a high net operating income by neglecting the properties and still get a high price when you sell, at least in periods when there is an abundance of capital and also principal agent problems in the banking system.

The second possible explanation is simply that the decision makers in the property company did not care about the sales price as the decision makers bad not invested their own money in the company. This was e.g. the case in the company described in Ahlgren \& Segerborg (2010). The people who started the company were highly paid as managers and when the value of the properties increased the company could report large profits and pay high bonuses to the managers. Maybe they were all the time aware of the high risk that the company would go bankrupt in a future recession. Banks and investors were however willing to provide capital to the company at rather low interest rates. The whole structure would in this interpretation be built up to swindle investors. The exit strategy of the decision makers would simply be to let the company go bankrupt and the investors would then take the fall, while the managers would go on to other businesses. A number of such bankruptcies have been observed in Sweden in 2010 and 2011.

With hindsight from the financial crisis it is possible to see that both the exit strategies described above could be possible. This raises another issue and that is how the firms could get the money from the investors in the first place. A combination of irrational investors and principal agent problems in the banking system might then seem to be the best guesses. Lind (2009) discusses the general features that can create a bubble and mostofthese conditions are relevant also in the case described in this article.

\section{Conclusions}

\subsection{Putting the explanatory puzzle together}

The conjecture presented in this article is that the development in the Herrgården area can, be seen as the result of the interaction between the following factors:

A property company led by individuals that could gain by a strategy that, from the perspective of a normal company, is unprofitable. This possibility was opened up by different types of 
irrationalities and principal agent problems on the capital market, which made it possible to raise capital for such investments.

A tenant structure in the area that meant that the majority of the tenants accepted a housing standard that was below the legal norm. The hypothesis is that some households profited from the no-questions-asked-policy of the landlord, while others were afraid of the first group. Some did not know that they could take legal action against the landlord and some were planning to move out soon.

We want to underline that this should be seen more as a reasonable conjecture than as proven facts.

\subsection{Policy implications}

The development in Herrgården also indicates that there are some holes in the Swedish housing legislation and we believe that the following policy lessons can be drawn.

There are, as mentioned in the introduction, laws about building maintenance and the municipality can carry about inspections and demand corrections from a property owner. This is however not done and the reason seems to be that the law about receivership is based on the idea that the tenants should go to court and complain if the landlord neglects maintenance, typically with the help of the Tenant's Union. As this has worked well for many years the municipality never had to do anything and therefore "forgot" about their responsibility.

The Herrgården case shows that relying on actions from the tenants does not always work. In this area there were households that for a number of reasons do not go to the courts. It was also an area where the Tenants Union was weak and where they did not feel that it was their responsibility to act.

The first part of the solution, as we see it, must be that the municipality also in reality takes the responsibility that it already formally has. They must inspect properties on a regular basis in areas where poor people live.

The second change that we think is needed concerns the sanctions in the case of repeated neglect. Receivership has not worked very well and a stronger and quicker sanction seems necessary. The first step would be high fines if the quality is below what is acceptable and even higher fines if the standard isn't quickly raised. At the same time the rent should be reduced retroactively and as long as the standard is not raised. If this does not work it should be possible to force the owner to sell the property on an executive auction rather quickly if maintenance is not improved and/or fines not paid.

These changes would all reduce the expected profitability of the slum strategy, and it would much quicker than the rules today show providers of capital if their investment managers are following a very risky strategy from an investor's perspective. 


\subsection{Theoretical implications}

Even if the primary aim of this article is to explain the case of Herrgården it also has implications for some general issues about the workings of the rental market.

- Rent regulation: If rents are regulated to a level that creates queues in most areas, it is more difficult for households to move aud this should make the slum-lord strategy easier to implement. This aspect of rent regulation is however seldom discussed. ${ }^{8}$

- Asymmetric information and its effects: From a landlord perspective, the question is how much aud by which methods the landlord should collect information about tenant-behaviour. The slumlords'no-questions asked policy represents one extreme policy. From a household perspective, the problem is to get information about the behavior of different landlords in order to avoid potential slum-lords. The easier it is to get such information, the more risky should the slumlord strategy be, and policies to increase trausparency could be motivated from a welfare perspective.

\subsection{Future empirical research}

The research presented here eau be developed in two directions: one quautitative and one more qualitative. The first concerns how common the development described here was: How many properties were in the hands of this type of owner aud how far did different areas deteriorate? As mentioned in the Methods section above, it is also very important with more phenomenological/anthropological studies in order to better understand how people in the area saw their options and why they made certain choices. This would also make it possible to test some of the more speculative hypotheses presented here.

\section{Post-Script}

After the media attention given to the Herrgården case the company promised to increase investment in the area and a maintenance plan has been put forward.

\section{References}

Ahlgren, M, and Segerborg, G. (2010) Landic Property Group - A Case Study. Candidate thesis, Department of Building and Real Estate Economics, Royal Institute of Technology. Stockholm

Blomé, G. (2010) Ekonomiska effekter relaterat till åtgärder i bostadsområden. Boverket. Karlskrona.

\footnotetext{
${ }^{8}$ See for example the artides published in the special issue on rent regulation in Swedish Journal of Economic Policy, issue, vol 1O, 2003.
} 
Blomé, G. (2011) Organizational and economic aspects of housing management in deprived areas. Doctoral dissertation, KTH Royal Institute of Technology, Stockholm.

Bevelander, P, Billing, P, Bruzeus, L Poppola, M, Salameh, E-K and Wigerfelt, B. (2000) Storstadssatsningen i Rosengård - Ett nationellt exempel. Utvärdering av programområde "skola" och "lokalt utvecklingsarbete" in IMER:s utvärdering av storstadssatsningen $i$ Rosengård, Malmö, storstadssatsningen i Rosengård 2000-2001. IMER, Malmö Högskola.

Bevelander, P, Billing, P, Bruzeus, L Poppola, M, Salameh, E-K and Wigerfelt, B. (2001) Halvägs på väg vart? Utvärdering av programområde "skola" och "lokalt utvecklingsarbete" in IMER:s utvärdering av storstadssatsningen i Rosengård, Malmö, storstadssatsningen i Rosengård 2000-2001. IMER, Malmö Högskola.

Doran M, F, and Landis, R, A. (1980) Origin and Persistence of an Inner-City Slum in Nassau. Geographical Review: Vol70 No. 2. pp. 182-193.

Feijten, P, \& Van Ham, M. (2009) Neighbourhood change, Reason to leave? Urban Studies Vol 46; pp.2103-2122..

Hallin, P. Jashari, A. Listerborn, C. and Popoola, M. (2010) Det är inte stenarna som gör ont. Röster från Herrgården - om konflikter och erkännande. Mapius. Malmö Högskola.

Jönsson, F. (2005) What has enabled Acta's and Keops's large volumes of residential property acquisitions? Masters thesis, Department of Building and Real Estate Economics, Royal Institute of Technology. Stockholm.

Lilja, E. \& and Pemer, M (2010), Boendesegregation - orsaker och mekanismer En genomgång av aktuell forskning. Boverket, Karlskrona.

Lind, H. (2009) Price bubbles in honsing markets: Concept, theory and indicators, International Journal of Housing Markets and Analysis, Vol2 No. 1, pp 78-90.

Molina, L (2001) Den delade staden. Segregation och etnicitet i stadsbygden. Boréa Bokförlag. Umeå.

Neuwirth R. (2006) Shadow Cities, Routledge, New York.

O'Flaherty, B. (1993) Abandoned buildings: A Stochastic Analysis. Journal of Urban Economics, Vol34 No 1, pp. 43-74.

Popoola, M, (1998) The social interplay on Romana Platsa. Lund dissertations in sociology, Lund.

Popoola, M. (1999) Trångt i Herrgårdsmiljö. Rapport om trångboddhet på Herrgården. IMER, Malmö Högskola.

Popper, K, (1963), Conjectures and refutations: the growth of scientific knowledge. Routledge, London. 
Quigley J. (2000) A Decent Home : Housing Policy in Perspective. Brookings-Wharton Papers on Urban Affairs, pp. 53-99.

Reinhart, C \& Rogoff, K (2008), Is the 2007 U.S. Sub-Prime Financial Crisis So Different? An International Historical Comparison". American Economic Review, Vol98 No. 2, pp. 339-344.

Ristilammi,P-M (1994) Rosengård och den svarta poesin: en studie av modern annorlundahet. Östlings förlag, Stockholm.

SFI/IPD Sweden Residential Property Index 2009, Stockholm 2010.

Stokes, C. J. (1962) A Theory of Slums. Land Economics, Vol38 No. 3, pp. 187-197.

Yearbook of Housing and Building Statistics 2010. Official Statistics of Sweden, Statistics Sweden, 2010

Öresjö, E. (1996) Att vända utvecklingen. Kommenterad genomgång av aktuell forskning om segregation I boendet. SABO. 